\title{
POTICANJE ČITANJA KOD STUDENATA KAO JEDNA OD ZADAĆA SUVREMENIH VISOKOŠKOLSKIH KNJIŽNICA
}

\author{
ENCOURAGING READING HABITS AMONG \\ STUDENTS AS ONE OF THE ROLES OF CONTEMPORARY \\ ACADEMIC LIBRARIES
}

Zorica Antulov

Knjižnica, Sveučilište u Zadru

zantulov@unizd.hr

UDK / UDC: 028-057.875:027.7

Stručni rad / Professional paper

Primljeno / Received: 31. 1. 2021.

Prihvaćeno / Accepted: 20. 8. 2021.

\section{Sažetak}

Cilj. Uloga čitanja za emocionalni i intelektualni napredak mlade osobe neupitna je te je stoga prepoznata i kao česta tema znanstvenih i stručnih radova koji se bave čitanjem kod mladih, skupine u koju pripada i većina studenata. Cilj je rada ukazati na važnost poticanja navika čitanja kod studenata, neovisno pritom o svrsi čitanja, i na ulogu koju u postizanju većeg stupnja razumijevanja pročitanog teksta u studentskoj populaciji imaju visokoškolske knjižnice. Osobito se želi naglasiti važnost poticanja rekreativnog čitanja koje se na akademskoj razini često nepravedno zanemaruje.

Metoda. Proučavanjem radova pisanih na temu čitanja kod mladih, kao i radova koji se izravno ili neizravno dotiču teme čitanja kod studentske populacije i usporedbom dosadašnjih spoznaja o toj temi, dolazi se do određenih zaključaka analiziranih i sintetiziranih u ovom tekstu.

Rezultati. Iznimna korist koju za cjeloviti razvoj osobe donosi viši stupanj čitateljske pismenosti prepoznata je i kada se radi o studentskoj populaciji. Takav stupanj pismenosti postiže se tek učestalim čitanjem kvalitetnih tekstova, neovisno radi li se o tekstovima obrazovnog karaktera ili pak tekstovima za razonodu. Pa ipak, unatoč

Vjesnik bibliotekara Hrvatske 64, 2(2021), 265-284

ISSN 0507-1925 
ili upravo zbog njihove usmjerenosti na podupiranje odgojno-obrazovnog i znanstveno-istraživačkog rada matične ustanove, uloga visokoškolskih knjižnica u poticanju čitanja je poprilično marginalizirana. Štoviše, kad je riječ o rekreativnom čitanju ponekad je i svjesno nepravedno zapostavljena. Budući da je viši stupanj rekreativnog čitanja, između ostalih dobrobiti koje donosi, povezan i s boljim akademskim uspjehom studenata, pojedine visokoškolske knjižnice s vremenom postaju otvorene prema toj svojoj ulozi: osmišljavaju kreativne načine poticanja čitanja kod studenata, kao i puteve k razvijanju vještina potrebnih za razumijevanje pročitanog teksta.

Originalnost/Vrijednost. Zbog pozitivnog utjecaja čitanja na intelektualni i emocionalni razvoj mlade osobe, u domaćoj stručnoj literaturi opravdano nailazimo na veći broj radova na tu temu. Kroz ukazivanje na izniman doprinos koji za intelektualni razvoj studenata, a time i kvalitetu znanstvenog rada same ustanove, radom na poticanju čitanja mogu dati visokoškolske knjižnice, ovaj se rad pridružuje spomenutoj grupi radova iznimno vrijedne i osjetljive tematike.

Ključne riječi: čitateljske vještine, studenti, visokoškolske knjižnice

\section{Abstract}

Purpose. The role of reading in the emotional and intellectual development of a young person is unquestionable and is therefore recognized as a frequent topic of scientific and professional papers dealing with reading among young people, a group to which most students belong. The aim of this paper is to point out the importance of encouraging students' reading habits, regardless of the reading purpose, and to point out the role that academic libraries have in achieving a greater degree of reading comprehension among the student population. A particular emphasis is placed on the importance of encouraging recreational reading, which is often unfairly neglected at the academic level.

Method. A literature review was conducted on papers written on the topic of reading habits of young people, as well as papers that directly or indirectly deal with the topic of reading in the student population. Through analysis and comparison of the results of previous studies certain conclusions were drawn.

Results: A distinct benefit that a higher level of reading literacy adds to the overall development of a person is also recognized within the student population. Such a level of literacy is achieved only by frequent reading of quality texts, regardless of the text's nature, whether it is educational or recreational. Yet, despite of, or precisely because of their focus on supporting education and research within their parent institution, the role of academic libraries in reading promotion is rather marginalized. Moreover, when it comes to recreational reading, it is also sometimes purposely unfairly neglected. Since a higher level of recreational reading, among other benefits, is associated with students' greater academic achievement, some academic libraries accept this role: they devise 
creative ways to encourage reading among students, as well as ways to develop reading comprehension skills.

Originality / Value. Due to the positive impact of reading on the intellectual and emotional development of a young person, we justifiably come across a larger number of papers on this topic in the Croatian professional literature. By pointing out the exceptional contribution that academic libraries can make in the intellectual development of students, and thus to the quality of scientific work of the institution itself, by working to encourage reading, this paper joins the before mentioned group of papers on this extremely valuable and sensitive topic.

Keywords: academic libraries, students, reading skills

\section{Uvod}

„Oni koji znaju čitati vide dvostruko. "I

Mada su vrijednost čitanja prepoznali još drevni narodi, o čemu svjedoče i navedene riječi atičkog pjesnika Menandera iz četvrtog stoljeća prije Krista, činjenica je da je pismenost kroz povijesna razdoblja bila omogućena samo rijetkima. Oni koji su znali čitati i pisati činili su svojevrsnu intelektualnu elitu svog doba.

Danas, kad je pravo na osnovnu pismenost prepoznato kao temeljno ljudsko pravo, ${ }^{2}$ pa osnovna pismenost više nije rezervirana isključivo za intelektualne elite, učestalost čitanja te stupanj čitateljske pismenosti i dalje čine bitan element koji uvelike utječe na daljnji intelektualni i profesionalni razvoj osobe. Poticanje čitanja, osobito u djece i mladih (prema N. Mikuletič ${ }^{3}$ mladost se definira kao razdoblje koje započinje oko jedanaeste i traje do ranih dvadesetih godina) zadaća je svakog društva koje brine o svojoj budućnosti. Čitanjem djeci od ranih nogu u obitelji, promicanjem knjižničnih službi i usluga i sličnim aktivnostima kojima se stvaraju rane navike čitanja svakako se uvelike doprinosi tom vrijednom cilju. Rezultati istraživanja koje je proveo M. Taylor ${ }^{4}$ na Sveučilištu Oxford u Velikoj Britaniji, pokazuju kako su ispitanici koji su kao šesnaestogodišnjaci više čitali, u kasnijim godinama postigli znatno viši uspjeh u profesionalnom životu. Viši stu-

\footnotetext{
1 Menander. Sententiae 657. // Works. / ed. W. G. Arnott. Cambridge; London, 1969. Citirano prema: Manguel, A. Povijest čitanja. Zagreb: Prometej, 2001. Str. 199.

2 Usp. Opća deklaracija o ljudskim pravima. [citirano: 2020-10-10]. Dostupno na: http://www. mvep.hr/custompages/static/hrv/files/081210_deklaracija_ljudska_prava.pdf.

3 Mikuletič, N. Biblioterapija u školskoj knjižnici ili razgovor o knjizi. // Vjesnik bibliotekara Hrvatske 53, 2(2010), str. 135.

4 Usp. University of Oxford. Reading at 16 linked to better job prospects. // ScienceDaily, 9 May (2011). [citirano: 2020-10-22].

Dostupno na: www.sciencedaily.com/releases/2011/05/110504150539.htm.
} 
panj čitateljske pismenosti bio je povezan i s većom vjerojatnošću nastavka školovanja. ${ }^{5}$ Studenti, skupina uglavnom mladih ljudi koja nakon završetka srednje škole nastavlja obrazovanje težeći visokom obrazovanju, a koja je, s ostalim akademskim građanima, odraz i pokazatelj obrazovne slike društva, pripadaju grupaciji ljudi koja bi za današnje društvo trebala biti ono što su spomenuti, pismenošću povlašteni pojedinci davnih doba, bili za svoje.

Pojedinci s višim stupnjem čitateljske pismenosti dobrobit su svakog društva, a studenti bi to, dakle, za svoje društvo trebali biti. Budući da se čitanjem obogaćuje vokabular osobe, stupanj njezine pismenosti, njezin kognitivni te intelektualni razvoj, te da odgonetavanje pisanih znakova čini misaoni proces čitanja svojevrsnom intelektualnom vještinom, ${ }^{6}$ očito je da je korist koju ta skupina mladih ljudi može imati od čitanja izuzetna. Uz tome pridodanu spoznaju kako se učestalim čitanjem razvija sposobnost shvaćanja značenja sadržaja, zauzimanja kritičkog stava prema njemu kao i mogućnost stvaralačke prerade istog, ${ }^{7}$ te, $\mathrm{s}$ druge strane, zapaženi nedostatak razumijevanja pročitanog teksta kod većine mladih $1 j u$ di $^{8}$ pa tako i studenata, očito je da zadaća visokoškolskih knjižnica u poticanju čitanja u toj populaciji zaista nije bezrazložna.

Dapače, iznimno je bitno poticati studente na čitanje, podučavati ih čitanju s razumijevanjem i ne dopustiti da im ono postane tek obaveza koju treba izvršavati prije ispunjavanja zadanog im obrazovnog zadatka. Visokoškolske knjižnice, kao bitne sastavnice visokoškolskih ustanova, pritom mogu odigrati značajnu ulogu.

\section{Uloga visokoškolskih knjižnica u poticanju čitanja}

\subsection{Svrha i funkcije čitanja te poticanje čitanja s razumijevanjem}

Kad se kaže da se primarna zadaća visokoškolske knjižnice očituje u podupiranju nastavnih i znanstvenih procesa, ${ }^{9}$ uglavnom se pomišlja na njezinu nezaobilaznu ulogu u osiguravanju literature i ostale građe potrebne za uspješno studiranje, osiguravanje prostora za rad i učenje, edukaciju studenata za samostalno služenje informacijskim izvorima i slične aktivnosti koje su neophodne za uspješno odvijanje visokoškolske nastave. Mada je prema „Standardima i smjernicama razvoja i

\footnotetext{
Usp. Isto.

6 Usp. Kleedorfer, J.; M. Mayer; E. Tumpold. Čitati s voljom i razumom. Koprivnica: Hrvatsko čitateljsko društvo, 1998. Str. 18.

7 Usp. Isto.

8 Usp. Peti-Stantić, A. Čitanjem do (spo)razumijevanja: Od čitalačke pismenosti do čitateljske sposobnosti. Zagreb: Naklada Ljevak, 2019. Str. 102.

9 Usp. Petr Balog, K. Prema kulturi vrednovanja u visokoškolskim knjižnicama. Osijek: Filozofski fakultet Sveučilišta, 2010. Str. 31.
} 
uvođenja najbolje prakse u visokoškolskim knjižnicama u Republici Hrvatskoj“10 čitanje prepoznato kao jedna od posebnih zadaća tih knjižnica, pitanje je pripada li poticanje na čitanje, osobito ono koje nije usmjereno isključivo na znanstvene, stručne i slične tekstove neophodne za studiranje, zaista u aktivnosti koje su na razini tih knjižnica prepoznate kao neophodne. Činjenica je da razvijene čitateljske vještine stoje u osnovi kompetencija svih „novih pismenosti““11, stoga se podrazumijevaju i tijekom informacijskog opismenjavanja studenata, neizostavne i iznimno važne usluge koju u novije vrijeme svojim korisnicima nudi veći broj visokoškolskih knjižnica. Pod informacijskim opismenjavanjem podrazumijeva se skup sposobnosti koje čine prepoznavanje, pronalaženje, vrednovanje i učinkovito korištenje informacija, ${ }^{12}$ za što je, dakle, spomenuta vještina neophodna. Podučavanje osobinama, pronalaženju i služenju te razlučivanju kvalitetnih (točnih, aktualnih, dostupnih i upotrebljivih ${ }^{13}$ ) od nekvalitetnih ili manje kvalitetnih izvora informacija, pritom je iznimno bitno. Čitalačka pismenost pretpostavlja sposobnost dekodiranja teksta, poznavanje i analizu značenja riječi i teksta u cjelini, poznavanje gramatičkih struktura, ali i čitanje između redaka, sposobnost otkrivanja svrhe teksta, ${ }^{14}$ kao i prethodno poznavanje područja o kojemu se čita. ${ }^{15}$ Budući da se upravo na temelju odabranih izvora oblikuje novo znanje, kvaliteta upoznavanja područja o kojem se čita (uči) umnogome će, dakle, ovisiti i o kvaliteti o odabranih izvora. Iz rečenog se može zaključiti kako će visokoškolske knjižnice i kroz svoj rad na informacijskom opismenjavanju studenata odigrati važnu ulogu u poticanju njihove čitalačke pismenosti.

Govoreći općenito o čitanju kod studenata, ponajprije treba krenuti od svrhe, odnosno cilja na koji je njihovo čitanje usmjereno.

10 Usp. Standardi i smjernice razvoja i uvođenja najbolje prakse u visokoškolskim knjižnicama. [citirano 2021-03-04]. Dostupno na: https://www.hkdrustvo.hr.

11 Usp. Juric, M. Čitanje u tiskanom i digitalnom okruženju: Doktorski rad. Zadar: Sveučilište u Zadru, 2017. Str. 53. [citirano: 2020-06-10]. Dostupno i na: http://urn.nsk.hr/ urn:nbn:hr:162:167435.

12 Usp. Lau, J. Smjernice za informacijsku pismenost u cjeloživotnom učenju: Završna verzija. Zagreb: Hrvatsko knjižničarsko društvo, 2011. Str. 21.

13 Usp. Informacije: Gdje su i kako ih pronaći. [prezentacija] [citirano: 2020-12-05]. Dostupno na https://www.pravo.unizg.hr/_download/repository/prezentacija_za_postdiplomante.ppt.

14 PISA 2009: Čitalačke kompetencije za život. / uredila M. Braš Roth. Zagreb: Nacionalni centar za vanjsko vrednovanje obrazovanja - PISA centar, 2010. Str. 9-10.

15 Dimzov, S. Uloga sveučilišne knjižnice u digitalnom okruženju s obzirom na informacijsko ponašanje studenata humanističkih znanosti: Doktorski rad. Zadar: Sveučilište u Zadru, 2016. Str. 18. [citirano: 2021-03-03]. Dostupno i na: https://urn.nsk.hr/urn:nbn:hr:162:880974. 
Smatra se da čitanje nije jednostavna, već kompleksna i varijabilna aktivnost, pa također ne postoji ni samo jedna svrha čitanja. ${ }^{16}$ Prema R. Paul i L. Elder ${ }^{17}$ postoje tri osnovne svrhe čitanja: čitanje poradi razumijevanja opće ideje, odnosno smisla teksta, za što je nerijetko dovoljno tek letimično proučiti tekst; usmjereno čitanje koje podrazumijeva usredotočeno i pažljivo čitanje funkcionalnih, složenih i zahtjevnih tekstova (umjetničkih i ne umjetničkih) te čitanje iz razonode.

U osnovi prve i druge navedene svrhe čitanja stoji cilj zadovoljavanja kognitivno-utilitarne ${ }^{18}$ komponente, pri čemu treba istaknuti da je za neke obrazovne tekstove studentima zaista nužna usredotočenost i duboka pozornost, a za druge je dovoljno tek letimično pregledavanje teksta. ${ }^{19}$ Treća spomenuta svrha čitanja usmjerena je na afektivno-hedonističke ${ }^{20}$ aktivnosti. Drugačije rečeno, spomenuta svrha čitanja nije u funkciji ispunjavanja zadanih obrazovnih zadataka studenata, već se odnosi isključivo na uživanje u čitanju. Takvo je čitanje, kada se govori o toj skupini ljudi, vrlo često nepravedno zaboravljeno, a vrijednost mu umanjena.

U stručnoj literaturi o čitanju kod odraslih i adolescenata navode se četiri osnovne funkcije čitanja: funkcija ispunjavanja zadanog obrazovnog zadatka, funkcija individualnog razvoja, funkcija uživanja u čitanju i funkcija bijega od svakodnevice. ${ }^{21}$ Nije upitno da je prva navedena funkcija čitanja (funkcija ispunjavanja zadanog obrazovnog zadatka) za studente iznimno bitna. Druga navedena funkcija (funkcija individualnog razvoja) podrazumijeva stjecanje iskustva pa ni nju neće biti problem prihvatiti kao podjednako važnu, korisnu i iznimno bitnu za akademski uspjeh studenata. Naime, već je spomenuto da su mladi ljudi, dakle i većina studenata, neiskusni i nedostaje im sposobnost da „pročitaju“ određene životne situacije te da se snađu u izmijenjenim okolnostima. Kroz razmišljanje o sebi, potaknuto određenim rečenicama u tekstu, citatima, situacijama u kojima

16 Usp. Liu, Z. Reading behavior in the digital environment: Changes in reading behavior. // Journal of Documentation 61, 6(2005), str. 702. DOI: https://doi.org/10.1108/00220410510632040.

17 Usp. Paul, R.; L. Elder. How to read a paragraph: The Art of close reading. 2nd ed. Lanham [etc.]: Rowman \& Littlefield, 2013. Str. 17-18. [citirano: 2020-02-20]. Dostupno na: https://books.google.hr/books?id=BDWbDwAAQBAJ\&printsec=frontcover \&d$\mathrm{q}=$ how + to + read $+\mathrm{a}+$ paragraph $\& \mathrm{hl}=\mathrm{hr} \& \mathrm{sa}=\mathrm{X} \& \mathrm{ved}=0$ ahUKEwiUra-P1rLlAhUMbcAKHUP5C sIQ6AEIJjAA\# $\mathrm{v}=$ onepage $\& \mathrm{q}=$ how $\% 20$ to $\% 20 \mathrm{read} \% 20 \mathrm{a} \% 20$ paragraph $\& \mathrm{f}=$ false.

18 Usp. Pšihistal, R. O književnosti kroz dimenziju čitanja/hranjenja. // Zbornik radova Čitanje za školu i život, IV. simpozij učitelja i nastavnika hrvatskoga jezika. / urednik M. Mićanović. Zagreb: Agencija za odgoj i obrazovanje 2013. Str. 49. [citirano: 2021-03-02]. Dostupno na: https://www.azoo.hr/app/uploads/uvezeno/images/izdanja/citanje/06.html.

19 Usp. Fulgosi, S. Usmjereno čitanje. // Zbornik radova Čitanje za školu i život, IV. simpozij učitelja i nastavnika hrvatskoga jezika. / urednik M. Mićanović. Zagreb: Agencija za odgoj i obrazovanje, 2013. str. 116. [citirano: 2020-02-02]. Dostupno na: https://www.azoo.hr/app/ uploads/uvezeno/images/izdanja/citanje/12.html.

20 Usp. Pšihistal, R. Nav. dj., str. 49.

${ }^{21}$ Usp. Tomašević, N. Istraživanje stajališta o čitanju i njihov utjecaj na nakladništvo: Ocjena zainteresiranosti za književne vrste. // Libellarium 1, 2 (2008), str. 223-224. DOI: https://dx.doi. org/10.15291/libellarium.v1i2.131. 
se nađu likovi o kojima se čita i sl., oni stječu nova iskustva i jasniji uvid u sebe. Isto tako, stječu i određenu mudrost po pitanju poznavanja drugih pojedinaca $\mathrm{i}$ svijeta. Međutim, uz posljednje se dvije funkcije, budući da nisu usmjerene na cilj učenja, ponekad veže pitanje smislenosti na akademskoj razini. Čitanje iz razonode znatno obogaćuje ne samo emocionalni već i intelektualni život čitatelja, ${ }^{22}$ a studija „To read or not to read“ ${ }^{23}$ pokazuje kako stupanj takvog čitanja korelira s akademskim uspjehom osobe. ${ }^{24}$ Budući da je podupiranje odgojno-obrazovnog i znanstveno-istraživačkog rada studenata u osnovi poslanja visokoškolskih knjižnica, takve se spoznaje ne bi smjele zanemarivati. Kao posljednja funkcija čitanja spominje se funkcija bijega. Bijeg od svakodnevice svima je povremeno potreban, a studenti nisu izuzetak. Zahtjevan studijski program, preopterećenost, udaljenost od obitelji i mjesta stanovanja, prelazak iz jednog ,zaštićenog“ načina života koji je omogućavalo djetinjstvo, u slobodu, ali i nesigurnost mladenaštva nerijetko u studentima može izazvati razne negativne osjećaje. Istraživanje koje su zbog primijećenog povećanja broja psihičkih poremećaja u studentskoj populaciji provele S. Mamić i M. Nekić ${ }^{25}$ donosi po tom pitanju zaista zabrinjavajuće rezultate. Naime, prema rezultatima spomenutog istraživanja, gotovo jedna trećina studenata tijekom studiranja ima simptome nekog psihičkog poremećaja. ${ }^{26}$ Bijeg od stvarnosti koji nudi dobra i pravilno odabrana knjiga možda može u takvim slučajevima biti iznimno važan. Rasterećenje i oslobođenje od stresa koje takva knjiga može polučiti, može biti barem jedan segment pomoći za postizanje boljeg psihičkog stanja studenata, što će naposljetku olakšati i učenje. Visokoškolske knjižnice kao mjesta gdje studenti izvršavaju svoje brojne obrazovne zadatke, ali i mjesta neformalnog druženja studenata, ujedno mogu biti i mjesta usmjerena na provođenje aktivnosti kojima se smanjuje anksioznost kod studenata. Jedna od takvih aktivnosti visokoškolskih knjižnica jest provođenje razvojne biblioterapije ${ }^{27}$ i razvijanje svijesti o svim aspektima njezine korisnosti za studente. Razumijevanje, a potom i prevladavanje osobnih negativnih emocija do čega dolazi kroz faze identifikacije, projekcije, katarze i uvida ${ }^{28}$ otvara put ka lakšem i kvalitetnijem studiranju.

22 Usp. Fulgosi, S. Usmjereno čitanje. Nav. dj., str. 116.

23 Usp. To read or not to read: A Question of national consequence: Research Report 47. Washington DC.: National Endowment for the Arts, Office of Research and Analysis, 2007. [citirano: 2020-01-10]. Dostupno na: https://www.arts.gov/sites/default/files/ToRead.pdf.

24 Usp. Isto, str. 5-6.

25 Usp. Mamić, S.; M. Nekić. Anksioznost kod studenata: Uloga perfekcionizma, netolerancije neizvjesnosti, ruminacije i usredotočene svjesnosti. // Društvena istraživanja 28, 2(2019), str. 295-314. DOI: https://doi.org/10.5559/di.28.2.06.

26 Usp. Isto. str. 309.

27 Usp. Krpan, K.; I. Klak Mršić; V. Cej. Primjena razvojne biblioterapije u radu s djecom i mladima u narodnoj knjižnici. // Vjesnik bibliotekara Hrvatske 61, 1(2018), str. 348. DOI: http:// doi.org/10.30754/vbh.61.1.621.

28 Usp. Rudež, J. Bibliografska metodologija. // Hrvatski 2, 1/2(2004), str. 56-66. 
Očito je, dakle, da i posljednje dvije funkcije (funkcija uživanja u čitanju i funkcija bijega od svakodnevice) imaju iznimnu vrijednost kako za osobni emocionalni razvoj studenta tako i za intelektualni razvoj i akademska postignuća.

Zbog uočene paralele između interesa za čitanje i učenja (potrebe za nastavkom školovanja), ${ }^{29}$ čitanje kod studenata, neovisno o primarnom cilju čitanja, u visokoškolskim knjižnicama potrebno je što više poticati. Volja za čitanjem i vještina čitanja također su usko povezane,$^{30}$ a isto tako povezane su i različite vrste čitanja. Prema I. Stričević, ${ }^{31}$ čitanje kojem je cilj dobivanje informacija pozitivno djeluje na potrebu čitanja iz užitka i obrnuto: u ranoj dobi stečena navika čitanja iz užitka kasnije će pozitivno utjecati na akademske vještine. ${ }^{32}$

Pritom treba istaknuti i kako, neovisno o svrsi ili pak funkciji čitanja, razumijevanje pročitanog teksta ne smije izostati. Naime, nerijetko se događa da osoba ima sposobnost čitanja, ali joj nedostaje razumijevanje pročitanog. ${ }^{33} \mathrm{Kad}$ je riječ o djeci i mladim čitateljima, zanimljivo je da oni uglavnom imaju sposobnost automatiziranja raspoznavanja slova kao i integraciju istih u riječi, povezivanja riječi u rečenice te djelomičnog automatiziranja razumijevanja značenja mnogih riječi, sintagmi i rečenica. Oni shvaćaju značenje kao i promjenu značenja u slučaju promjene konteksta. Takvo razumijevanje rezultat je dotadašnjih iskustava koja je mladi čitatelj kroz život stekao. ${ }^{34}$ Međutim, mnogim mladim ljudima, skupini u koju ulazi i većina studenata, nedostaje iskustva. Njihovo znanje o svijetu mlado je poput njih samih, a za razvijanje širokog i kvalitetnog vokabulara potrebno je određeno vrijeme. Upravo je to razlog zbog kojega se ponekad gube kod viših razina čitanja. Složeni tekstovi postaju im problem i javlja se svojevrsna čitalačka nesigurnost. ${ }^{35}$ Govoreći o novim razinama pismenosti, G. Biancarosa i C. E. Snow $^{36}$ ističu kako suvremenim adolescentima nedostaje sposobnost svrhovitog čitanja, sposobnost odabira kvalitetnih tekstova za učenje te znanje o načinima kako se iz njih uči. Nedostaje im, nadalje, i sposobnost povezivanja postojećeg

\footnotetext{
29 Usp. University of Oxford. Nav. dj.

30 Usp. Kleedorfer, J.; M. Mayer; E. Tumpold. Nav. dj., str. 10.

31 Usp. Stričević, I. Čitanje u kontekstu školskih i narodnih knjižnica: Uloga knjižnica u poticanju funkcionalnog čitanja i čitanja iz užitka. // Čitanje - obaveza ili užitak: Zbornik. / priredila R. Javor. Zagreb: Knjižnice grada Zagreba, 2009. Str. 41-49.

32 Usp. Isto. str. 42.

33 Usp. Lasić-Lazić, J.; M. Laszlo; D. Boras. Informacijsko čitanje. Zagreb: Zavod za informacijske studije, 2008. Str. 27.

34 Usp. Peti-Stantić, A. Nav. dj., str. 101-102.

35 Usp. Isto.

36 Usp. Biancarosa, G.; C. E. Snow. Reading next: A Vision for action and research in middle and high school literacy: A Report to Carnegie Corporation of New York. 2nd ed. Washington: DC: Alliance for Excellent Education, 2006. [citirano: 2010-10-22]. Dostupno na: https:// www.carnegie.org/media/filer_public/b7/5f/b75fba81-16cb-422d-ab59-373a6a07eb74/ccny_ report_2004_reading.pdf.
} 
znanja s novim, a javlja se i problem nerazumijevanja uvjetovanog nepoznavanjem određenih riječi, kao i problem snalaženja u proturječnim sadržajima. ${ }^{37}$ Treba postojati svijest da je učenje čitanja s razumijevanjem trajni proces i da bi se, kao takvo, trebalo provoditi na svim obrazovnim razinama, pa tako i visokoškolskoj. Naime, u izravnu vezu s akademskim uspjehom dovodi se tek sposobnost čitanja koju prati istinsko razumijevanje pročitanog teksta, ${ }^{38}$ pri čemu bi visokoškolska knjižnica mogla dati značajan doprinos. Stoga bi jedna od glavnih zadaća visokoškolskih knjižnica orijentiranih na poticanje čitanja bila utvrđivanje osnovnih vještina potrebnih za čitanje s razumijevanjem.

Među takvim vještinama A. Peti-Stantić navodi i one jezične, poput razvoja fonološke svjesnosti i sposobnosti dekodiranja znakova, uočavanja strukture odlomka i teksta i sl., ali i one koje nisu isključivo jezične, npr. sposobnost razumijevanja tona kojim tekst odiše, stila, situacija na koje se u tekstu nailazi i sl., pa čak i piščeva stajališta i njegovih namjera. ${ }^{39}$ Smatra se kako se najčešći uočeni problemi odraslih čitača (a studenti bez obzira na svoju mladost to jesu) kriju upravo u nesposobnosti pronalaženja biti čitanog teksta, uočavanja pogrešaka te dovođenja postupka čitanja u izravnu vezu sa svrhom čitanja..$^{40}$ Navedene spoznaje mogu biti visokoškolskim knjižnicama smjerokaz za provođenje poduke čitanja s razumijevanjem sa studentima. Tako će se npr. kroz organizirano čitanje odabranih knjiga s raspravom o njima, utvrditi bit pročitanog te osvijestiti svrha čitanja, uočiti pogreške i razlozi nerazumijevanja određenih dijelova.

Proučavatelji čitanja kod studenata ukazuju na još neke probleme zbog kojih im duboko poniranje u tekst nije uvijek moguće. Jedan od njih leži u težnji za brzim dolaskom do informacija, uobičajenoj za mladu generaciju ${ }^{41}$ i rascjepkanosti, fragmentarnosti, selektivnosti i čitalačkoj površnosti povezanih s tim..$^{42}$ Činjenica je da su novi medijski jezici drugačiji od književnog jezika knjige. Internet i mobitel koriste pismo kojemu nedostaje glavni tekst, šifriran i skraćen jezik (npr. SMS i MMS), a kultura takvog skraćenog pisanja utječe i na kulturu čitanja. ${ }^{43}$ Čak i kada je riječ o duljim, zahtjevnijim tekstovima, na kakve su studenti tijekom studiranja upućeni, čitanje u $e$-okruženju nerijetko je usmjereno isključivo na istraživanje teksta, pri čemu se zbog mnogobrojnih hiperveza gubi mogućnost dubinske koncentracije, a zamjenjuje je tek djelomična pozornost usmjerena prema

37 Usp. Isto., str. 1.

38 Usp. Lasić-Lazić, J.; M. Laszlo; D. Boras. Nav. dj., str. 27.

39 Usp. Peti-Stantić, A. Nav. dj., str. 96-97.

40 Lasić-Lazić, J.; M. Laszlo; D. Boras. Nav. dj., str. 28.

${ }^{41}$ Lasić-Lazić, J.; S. Špiranec; M. Banek Zorica. Izgubljeni u novim obrazovnim okruženjima: Pronađeni u informacijskom opismenjivanju. // Medijska istraživanja 18, 1(2012), str. 133.

42 Usp. Juric, M. Nav. dj., str. 19.

43 Usp. Plevnik, D. Fortuna čitanja. Osijek: Hrvatsko čitateljsko društvo, 2006. Str. 32-34. 
tekstu. ${ }^{44}$ Studenti ne smiju biti odvojeni od svog doba, međutim, moraju biti svjesni i određenih negativnosti koje takvo čitanje donosi. Prihvaćanje novih medija ne bi smjelo značiti odbacivanje starih ${ }^{45}$ pogotovo kada se uzmu u obzir brojne dobrobiti čitanja tradicionalnih tekstova navedene u radu, a na koje se u knjižnicama treba ukazivati. Pažljivim odabirom i promišljanjem postupaka za poticanje čitanja s razumijevanjem, kao i pametnim odabirom knjižničnih izvora visokoškolske knjižnice mogu dati svoj osobiti doprinos. Treba postojati svijest da je ključ budućeg uspjeha studenta, još uvijek mlade osobe, ali u konačnici osobe na kojoj počiva obrazovna budućnost društva, upravo u takvom čitanju, neovisno pritom o kojoj se svrsi čitanja radi. ${ }^{46}$

\subsection{Važnost učestalog čitanja u slobodno vrijeme}

Govoreći o suvremenom sveučilišnom knjižničarstvu T. Aparac-Gazivoda ${ }^{47}$ ističe kako ono treba razvijati one usluge kojima će svakom članu sveučilišne zajednice biti omogućeno da pronađe odgovore na jednostavna pitanja, ali i tražene znanstvene informacije, omogući lakše svladavanje ispitnog gradiva, komunikaciju s kolegama putem raspoložive telekomunikacijske tehnologije, ali i pruži mjesto za ugodan boravak te da studentima pruži literaturu koja bi zadovoljila njihove potrebe za čitanjem u slobodno vrijeme.

Spomenuta povezanost čitanja u slobodno vrijeme s akademskim uspjehom, ${ }^{48}$ ali jednako tako i nezanemariva pomoć koju ono može dati za poboljšanje psihičkog stanja studenata (što opet utječe na njihov akademski uspjeh), razlog je zbog kojeg se zadaća visokoškolskih knjižnica u poticanju takvog čitanja u studenata ne smije umanjiti i izolirati od ostalih postupaka podupiranja odgojno-obrazovnog i znanstveno-istraživačkog rada matične ustanove.

Učestalim čitanjem raznolikih tekstova, studenti upoznaju nove svjetove, stječu stalno nova iskustva te se i njihova sposobnost čitanja s razumijevanjem poboljšava. Svaka je knjiga originalna, uvijek donosi nešto novo, pa je zbog te osobine ona dragocjena, a ujedno je i preporuka za druge, nove knjige, nova čitanja, nove spoznaje i njihove uvijek nove svjetove. Prema A. Peti-Stantić, tek stalnim

\footnotetext{
44 Usp. Dewan, P. Reading in the age of continuous partial attention: Retail-inspired ideas for academic libraries. // Reference \& User Services Quarterly 58, 3(2019), str. 180. DOI: http:// dx.doi.org/10.5860/rusq.58.3.7045.

45 Usp. Plevnik, D. Nav. dj., str. 35.

46 Usp. Peti-Stantić, A. Nav. dj., str. 102-103.

47 Usp. Aparac-Gazivoda, T. Ali študenti potrebujejo knjižnice in zakaj = Trebaju li studenti knjižnice i zašto?. // Knjižnica: glasilo Zveze bibliotekarskih društev Slovenije 40, 3/4(1996), str. 35-43.

48 Usp. To read or not to read. Nav. dj., str. 5-6.
} 
učenjem osoba postaje sve bolja u onome što uči. ${ }^{49}$ Povećanje znanja, i to upravo postupkom njegova stalnog ulančavanja i nadograđivanja (jer ono tek takvim načinom učenja postaje dugoročno) te razvoj i produbljivanje vokabulara mladih ljudi, mora biti zadaća obrazovnog sustava kojem je stalo do čitanja s razumijevanjem. ${ }^{50}$ Svijest o korelaciji stupnja čitanja iz razonode s akademskim uspjehom osobe $^{51}$ mogla bi djelovati poticajno na studente. Pa ipak, određena istraživanja kojima se provjerava učestalost takvog čitanja kod studenata ne pružaju baš optimističnu sliku.

Tako npr. rezultati istraživanja prikazani u spomenutoj studiji „To read or not to read“, pokazuju da čak $65 \%$ brucoša čita manje od jednog sata tjedno radi užitka ili ne čita uopće, ${ }^{52}$ a ni istraživanje čitanja zagrebačkih studenata o kojem u svom radu govori D. Bouillet ${ }^{53}$ ne donosi ohrabrujuće rezultate. Naime, prema rezultatima tog istraživanja, samo desetina studenata rado provodi slobodno vrijeme čitajući, ${ }^{54}$ a pretpostavka po kojoj bi studenti kao svojevrsna društvena elita, veći dio svog slobodnog vremena trebali posvetiti kulturnim i edukacijskim aktivnostima kroz rezultate tog istraživanja nije potvrđena. Takav je rezultat porazan i alarmantan te traži daljnja istraživanja radi utvrđivanja uzroka i njihova mogućeg otklanjanja. Kao jedan od mogućih uzroka navodi se istinska preopterećenost studenata, ali možda je riječ i o neorganiziranosti, kampanjskom učenju i sl ${ }^{55}$ Danas se sve više govori i o kroničnom nedostatku slobodnog vremena (sveopćoj jurnjavi) zbog kojeg se napuštaju forme tradicionalne kulture te se tako i sve manje vremena posvećuje čitanju. Smatra se da današnji mladi zapravo baš i nemaju vremena za njegovo kvalitetno provođenje pa se okreću brzoj komunikaciji na medijima kao sve češćem obliku međusobnog druženja. ${ }^{56}$

Način na koji mladi provode slobodno vrijeme jasno ocrtava duh vremena i stanje u društvu. Na interes za čitanje kao i na navike čitanja (kulturu čitanja) utječu i osobni, ali u velikoj mjeri i društveni čimbenici uvjetovani kulturnom tradicijom i

\footnotetext{
49 Usp. Peti-Stantić, A. Nav. dj., str. 102.

50 Usp. Isto. str. 102-103.

51 Usp. To read or not to read. Nav. dj., str. 5-6.

52 Usp. Isto, str. 8-9.

53 Usp. Bouillet, D. Slobodno vrijeme zagrebačkih studenata: Prilika za hedonizam ili samoostvarenje. // Sociologija i prostor 46, 3/4 (181/182)(2008), str. 341-367. [citirano: 202010-22]. Dostupno na: file:///D:/Downloads/Sociologija_i_prostor_2008_3_4_06_Bouillet.pdf.

54 Usp. Isto, str. 349.

55 Usp. Isto, str. 362-363.

56 Usp. Leburić, A. Mladi i čitanje: Knjiga kao element popularne kulture. // Knjiga i slobodno vrijeme: Zbornik radova. / Međunarodni interdisciplinarni stručni skup Knjiga i slobodno vrijeme, Split, Gradska knjižnica Marka Marulića, 24. rujna 2010. Split: Gradska knjižnica Marka Marulića, 2011. Str. 11.
} 
kulturnom politikom pripadajuće sredine.$^{57}$ Ako se čitanje u slobodno vrijeme doživljava kao zabavna i opuštajuća aktivnost tek kod desetine studenata,$^{58}$ situacija je zaista ozbiljna. Budući da visokoškolske knjižnice kao svoju primarnu zadaću imaju razvijanje usluga namijenjenih upravo toj skupini korisnika, one bi trebale dati svoj doprinos poboljšanju njihove kulture čitanja. Knjižnice se općenito, pa tako i visokoškolske, doživljava kao sponu između nakladnika i knjige s jedne i čitatelja s druge strane. Kao takve, one mogu i trebaju biti mjesta na kojima se potiče pismenost, razvija odnos prema tiskanim i elektroničkim publikacijama te potiče informacijski i čitateljski interes i navike. ${ }^{59}$ Drugačije rečeno, budući da je čitateljski angažman, dakle navike, interesi i stav prema čitanju, ono što najviše utječe na čitateljsku pismenost ${ }^{60}$ sve knjižnice za djecu i mlade, pa tako i visokoškolske, trebaju raditi na poticanju čitanja. Međutim, za razliku od narodnih knjižnica, čijim se uslugama i studenti često služe, ${ }^{61}$ a koje se obično doživljavaju kao korisnicima blisko, treće mjesto, ${ }^{62}$ uz visokoškolske knjižnice studenti ponekad doživljavaju svojevrsnu anksioznost. ${ }^{63}$ Akademska ozbiljnost, „hladnoća“ znanstvene i stručne literature, nesnalaženje u prostoru knjižnice, nepoznavanje postupaka pronalaženja i služenja informacijama uz osjećaj da „drugi znaju bolje“ te s tim povezan osjećaj vlastite inferiornosti ${ }^{64}$ zaista može dovesti do izbjegavanja knjižnice. Anketno istraživanje zadovoljstva korisnika Gradske knjižnice Zadar ${ }^{65}$ pokazuje kako čak i one usluge za koje bismo mogli pretpostaviti da će studenti radije koristiti u visokoškolskim knjižnicama, kakvo je, recimo, korištenje studijske čitaonice, studenti izrazito često koriste u narodnim knjižnicama koje posjećuju i do nekoliko puta tjedno. ${ }^{66}$ Ako se tome pridoda i uloga koju imaju narodne

57 Sabolović-Krajina, D. Neki aspekti čitalačke kulture mladih. // Vjesnik bibliotekara Hrvatske 32, 1/4(1989),str. 72.

58 Usp. Bouillet, D. Nav. dj., str. 349.

${ }_{59}$ Usp. Stričević, I.; S. Jelušić. Informacijske potrebe i čitateljski interesi građana Hrvatske. // Knjiga i slobodno vrijeme: Zbornik radova. / Međunarodni interdisciplinarni stručni skup Knjiga i slobodno vrijeme, Split, Gradska knjižnica Marka Marulića, 24. rujna 2010. Split: Gradska knjižnica Marka Marulića, 2011. Str. 23.

${ }^{60}$ Usp. Isto, str. 18.

${ }_{61}$ Usp. Antell, K. Why do college students use public libraries? A phenomenological study. // Reference \& User Services Quarterly 43, 3(2014), str. 227-236. [citirano: 2020-10-22]. Dostupno na: https://www.jstor.org/stable/20864204?seq=1\#metadata_info_tab_contents

${ }_{62}$ Usp. Velagić, Z. Povijesnost koncepcije knjižničnog trećeg prostora. // Narodne knjižnice kao treći prostor: 9. savjetovanja za narodne knjižnice u Republici Hrvatskoj: Zbornik radova. / uredile D. M. Gabriel i J. Leščić. Zagreb: Nacionalna i sveučilišna knjižnica, 2015. Str. 30.

${ }_{63}$ Usp. Mellon, C. A. Library anxiety: A Grounded theory and its development. // College \& Research Libraries 47, 2(1986), str. 160-165. [citirano: 2021-02-03] Dostupno na: https://crl. acrl.org/index.php/crl/article/view/14195/15641.

64 Usp. Isto, str. 163.

${ }^{65}$ Usp. Novak, H. Anketno istraživanje zadovoljstvo korisnika Gradske knjižnice Zadar. // Vjesnik bibliotekara Hrvatske 53, 3/4(2010), str. 140-157.

${ }^{66}$ Usp. Isto, str. 147. 
knjižnice u organiziranju kulturnih manifestacija te poticanju rekreativnog čitanja za sve dobne i društvene skupine, pa tako i za studente, možda se može postaviti pitanje smisla poticanja te vrste čitanja na razini visokoškolskih knjižnica. Međutim, ako postoji svijest da se knjižnične usluge ne razvijaju radi usluga, već su namijenjene korisnicima, a da su studenti glavni korisnici visokoškolskih knjižnica te spoznaja o važnosti koju upravo usluga poticanja čitanja ima na osobni i intelektualni razvoj pojedinca,${ }^{67}$ to se pitanje nikako ne bi smjelo postavljati. S druge pak strane, pitanje približavanja tih knjižnica svojim korisnicima u svrhu bolje usluge jest pitanje koje bi se moglo i trebalo postavljati. Lijepa, ali i kvalitetna literatura namijenjena rekreativnom čitanju te zanimljivi i dobro osmišljeni popularno-znanstveni programi kojima bi se poticalo čitanje, svakako bi mogli biti jedan od učinkovitih načina približavanja tih korisnika svojoj visokoškolskoj knjižnici. Knjižnice s dvojnom funkcijom, poput Gradske i sveučilišne knjižnice Osijek, po tom su pitanju u daleko povoljnijoj poziciji jer se u svom nastojanju osiguravanja dostupnosti svih vrsta informacija ne orijentiraju isključivo na članove akademske zajednice, već na najširi krug kako stvarnih tako i potencijalnih korisnika. Međutim, iz navedenih razloga i pojedine visokoškolske knjižnice stvaraju zbirku literature namijenjenu rekreativnom čitanju. ${ }^{68}$ Neke visokoškolske knjižnice poput Sweet Briar College's Cochran Library's Browsing Room i University of Michigan Undergraduate Library imaju dugu tradiciju postojanja, nadopunjavanja i osuvremenjivanja takvih zbirki koje sadrže povijesne romane, znanstvenu fantastiku, fikciju i sl. literaturu, ${ }^{69}$ ali i mnoge moderne visokoškolske knjižnice osnivaju takve zbirke osjećajući potrebu za njima. Nerijetko se one osnivaju na upit samih studenata. Pa ipak, ima i slučajeva gdje visokoškolske knjižnice odbijaju stvaranje takvih zbirki kao i rad na poticanju rekreativnog čitanja kod studenata. Glavni razlog tome nalazi se u shvaćanju da bi uloga visokoškolskih knjižnica u tom slučaju izišla iz njihova osnovnog djelokruga te se previše približila ulozi javnih knjižnica, kao i na mišljenju da bi se visokoškolske knjižnice više trebale orijentirati na stvaranje slike o sebi kao informacijskim ustanovama i knjižničarima kao informacijskim stručnjacima. ${ }^{70}$ Međutim, svijest o dobrobiti poticanja čitanja u studenata, kao i svijest da takvo poticanje služi samo na dobrobit cijele akademske zajednice, ne umanjujući pritom značaj ostalih ciljeva i zadaća koje visokoškolske knjižnice imaju u svrhu unaprjeđenja rada ustanove čije su sastavnice, sve se više razvija. Mnoge visokoškolske knjižnice zato razvijaju strategije za poticanje čitanja i to ne samo kod studenata već i kod drugih članova akademske zajednice.

67 Usp. To read or not to read. Nav. dj., str. 6.

68 Rathe, B.; L. Blankenship. Recreational reading collections in academic libraries. // Collection Management 30, 2(2006), str. 82. DOI: https://doi.org/10.1300/J105v30n02_06.

${ }_{69}$ Usp. Elliot, J. Academic libraries and extracurricular reading promotion. // Reference \& User Services Quarterly 46, 3(2007), str. 38. [citirano: 2020-10-02]. Dostupno na: https://www.jstor. org/stable/20864694.

70 Usp. Isto, str. 39. 
Kao primjere takve dobre prakse možemo navesti:

- zajedničko čitanje studenata organizirano na Sveučilištu u Buffalu

- program pod nazivom „Čitanje na trijemu“ na Sveučilištu u Daytonu u kojemu su studenti razgovarali o odabranoj pročitanoj knjizi

- ljetni natječaj za čitanje usmjeren prema zaposlenicima sveučilišta na Kalifornijskom San Diegu pod nazivom „Poštuj dobru knjigu“ i sl. ${ }^{71}$

Programi poticanja čitanja mogu se na razini visokoškolskih knjižnica provoditi samostalno, ali i u suradnji s drugim ustanovama koje djeluju na promicanju čitanja, npr. lokalnim narodnim knjižnicama, Hrvatskim čitateljskim društvom i dr. Kao jedan od takvih primjera suradnje može se navesti višegodišnje sudjelovanje Sveučilišne knjižnice u Zadru na manifestaciji „Zadar čita“, čiji je idejni organizator Gradska knjižnica grada Zadra. Studenti, pod vodstvom profesora i knjižničara, sudjeluju u toj manifestaciji kao aktivni sudionici i/ili kao zainteresirani posjetitelji, pri čemu je za aktivno sudjelovanje nužno dobro poznavanje i razumijevanje zadane teme i literature koja se proučava, interpretira i na popularno-znanstveni način predstavlja publici. Poticanje rekreativnog čitanja na razini tih knjižnica i, sukladno tome, poticanje razumijevanja pročitanog teksta, postiže se i organizacijom studentskih čitateljskih klubova (kroz razgovor o knjizi bogati se vokabular, ali i stvara iskustvo potrebno za dublje razumijevanje pročitanih tekstova), pjesničkih večeri, biblioterapijskih susreta, radionica kreativnog pisanja (a koje pritom traže iščitavanje mnogobrojnih tekstova određene tematike), aktivnim sudjelovanjem i suradnjom studenata i visokoškolskih knjižničara u obilježavanju simboličnih datuma posvećenih knjizi i čitanju koje se održavaju kako u svijetu, tako i u našoj domovini (kao što su npr. Svjetski dan knjige i autorskih prava (23. travnja), Dan hrvatske knjige (22. travnja), Godina čitanja (2021. godina), manifestacijama koje se organiziraju na razini većeg broja institucija u svrhu poticanja i pohvale čitanju (npr. Noć knjige) i sl. Pritom treba istaknuti da čitanje kvalitetnih i prilagođenih tekstova može uvelike pomoći i u prevladavanju anksioznosti kod studenata, pri čemu važnu ulogu može odigrati razvojna biblioterapija ${ }^{72}$ koju bi, kao što je spomenuto, visokoškolske knjižnice baš zato mogle i trebale provoditi. Korisnost, ali i zanimljivost takvih manifestacija i susreta čini i samu visokoškolsku knjižnicu zanimljivijim i studentima bližim mjestom, a tek takva ona zaista može privući studente i polučiti uspjeh u svojoj ulozi poticateljice čitanja, ali i u svim drugim ulogama orijentiranim na studente.

Nadalje, u samim bi visokoškolskim knjižnicama trebalo raditi na razvijanju svijesti da se poticanjem tih aktivnosti njihova uloga informacijskih ustanova, od-

71 Usp. Mahaffy, M. In support of reading: Reading outreach programs at academic libraries. // Public Services Quarterly 5, 3 (2009), str. 165. DOI: https://doi.org/10.1080/152289509029042 67.

72 Usp. Krpan, K.; I. Klak Mršić; V. Cej. Nav. dj., str. 348. 
nosno status visokoškolskog knjižničara kao informacijskog stručnjaka ne umanjuje, već dapače, još više promiče. To se očituje i kroz činjenicu da je za organizaciju svih tih aktivnosti na samom početku potrebno pronaći odgovarajuću literaturu. Dakle, ne bilo kakvu, već pomno odabranu, primjerenu cilju koji se želi postići i korisnicima na koje je aktivnost usmjerena. To mogu samo informacijski stručnjaci koji su upućeni u svoj posao: poznaju građu i načine dolaženja do nje, poznaju korisnike, ali imaju i organizacijske i suradničke sposobnosti te znanja za organiziranje i vođenje takvih događanja i susreta.

Međutim, čak i kad se visokoškolske knjižnice, svjesne dobrobiti takvoga čitanja, odluče za rad na promicanju rekreativnog čitanja kod studenata te stvore zbirku pomno odabrane, kvalitetne i mladima tematski zanimljive literature, a potom osmisle aktivnosti usmjerene na njegovo poticanje, interes za čitanje kod studenata može ostati upitan. Uz nedostatak slobodnog vremena i druge razloge spomenute kako u ovom radu tako i u proučenoj literaturi, ${ }^{73}$ jedan od važnijih razloga tome krije se u činjenici da mladi ljudi (pa tako i većina studenata) imaju izraženu sklonost k suvremenim medijima: bilo da se radi o televiziji, kinu, radiju ili internetu. ${ }^{74}$ Svjesni te činjenice, moramo se zapitati i o zanimljivosti knjige kao medija. Poznati pisac J. Franzen u knjizi eseja Kako biti sam ${ }^{75}$ ističe kako je zbog gledanja televizije, od koje nije mogao „odlijepiti oči“, nerijetko zapostavljao čitanje. Kad se to dogodilo „čovjeku od knjige“, ne bi bilo neobično da se događa i našim studentima. Da bi studentima knjiga zaista postala zanimljiv medij te da bi mogla konkurirati suvremenim medijima, visokoškolski knjižničari trebaju znati preporučiti literaturu za slobodno čitanje koja će toj skupini ljudi biti zanimljiva. Istraživanja interesa studenata za određenu literaturu, kao i njihovi prijedlozi, ovdje mogu biti iznimno važni. Studentima treba ukazati na dobrobiti, ali i na užitak koji čitanje može donijeti. Pritom treba paziti i na kvalitetu literature koja im se preporučuje. Uvijek treba birati kvalitetnu literaturu. Takva literatura ne zadovoljava čitatelja tek na kratke staze, nego ostavlja trag i vuče na nova čitanja. Tu je također iznimno bitna uloga visokoškolskog knjižničara: njegovo poznavanje literature, kvalitetnih izvora koji donose preporuke, poznavanje osobina mlade studentske populacije te njegov entuzijazam i prijateljski stav.

Kad se upozna sva istinska radost i oplemenjenje koje može pružiti upravo čitanje knjige i koje na taj isti način ne može pružiti niti jedan drugi medij, put ka daljnjem čitanju trebao bi biti ucrtan jednom za svagda. Naime, uza svu moguću dobrobit koju elektronički mediji mogu imati za stvaranje uspješnog i slobodnog društva te za razvoj aktivnih i produktivnih odraslih ljudi, čitanje u tom pogledu daleko moćnije. Drugačije rečeno, uloga je čitanja u poticanju intelektualnog i

73 Usp. Bouillet, D. Nav. dj., str. 363.

74 Usp. Leburić, A. Nav. dj., str. 11.

75 Franzen, J. How to be alone. New York: Farrar, Straus \& Giroux, 2002. Citirano prema: Plevnik, D. Nav. dj., str. 31. 
osobnog rasta pojedinca nezamjenjiva, ${ }^{76}$ a upravo na tom području, kada se radi o studentskoj populaciji, visokoškolske knjižnice mogu dati izniman doprinos.

\section{Zaključak}

Mada sposobnost čitanja više nije rezervirana samo za odabrane pojedince i staleže, studenti svakako čine dio društva koji bi trebao raditi ne samo na postizanju vještine tečnog čitanja već i na što boljem razumijevanju pročitanog teksta. Budući da je njihovo čitanje, kao i inače čitanje kod mladih, prepoznato kao selektivno i fragmentirano te da im, kao i mladim ljudima inače, nedostaje potrebnog životnog iskustva da bi mogli razumjeti i duboko osvijestiti sve pročitane dijelove teksta, visokoškolske knjižnice trebale bi dati svoj doprinos ne samo u poticanju interesa studenata za čitanje već i u poticanju boljeg razumijevanja pročitanih tekstova. To se može nastojati postići raspravljanjem o pročitanim tekstovima tijekom organiziranih susreta studenata (čitateljski klub studenata, pjesničke večeri i dr.), radionicama kreativnog pisanja i sl., odnosno svim onim aktivnostima u knjižnici kojima će se kroz otkrivanje biti teksta i osvještavanje svrhe čitanja te kroz uočavanje pogrešaka, otkloniti razlozi nerazumijevanja. Podučavanje studenata o služenju informacijskim izvorima (tijekom informacijskog opismenjavanja u knjižnici), pomaže im u razumijevanju osobina i pronalaženju „pravih“ izvora (tekstova) potrebnih za ispunjavanje zadanog im obrazovnog zadatka, a preporuka kvalitetne literature od strane knjižničara, može biti poticaj za rekreativno čitanje. Međutim, s obzirom na slab interes studenata za rekreativno čitanje, zapažen na temelju rezultata istraživanja prikazanih u ovom radu, dolazi se do zaključka kako poticanje čitanja u toj populaciji nije nimalo jednostavan zadatak. Ako se tome pridoda i anksioznost koju pojedini studenti osjećaju spram visokoškolskih knjižnica, a koja nije primijećena spram narodnih knjižnica, postavlja se i pitanje smislenosti rada visokoškolskih knjižnica na poticanju rekreativnog čitanja. Pa ipak, upravo bi visokoškolske knjižnice, budući da su studenti njihovi primarni korisnici, trebale biti „njihovo treće mjesto“, a usluga poticanja rekreativnog čitanja u toj populaciji jedna od usluga koje bi u njima trebale biti zastupljene. Stvaranjem zbirki literature za rekreativno čitanje, organizacijom raznolikih kulturnih i obrazovnih događanja, radionica i predavanja u svrhu poticanja čitanja i sl. ili pak ciljanim predavanjima i radionicama namijenjenim poticanju sposobnosti čitanja s razumijevanjem kod studenata, visokoškolske knjižnice mogu dati svoj istinski obol za budućnost sadašnjeg društva i društva budućih generacija. U težnji da postanu najtoplije i studentima najbliže sastavnice visokoškolske ustanove, one ne bi trebale zazirati od svoje funkcije ,poticateljica“ čitanja te bi trebale svjesno i slobodno poticati rekreativno čitanje studenata, što se ponekad, u strahu od nedostatne razine ,znanstvenosti“ događa.

76 Usp. To read or not to read. Nav. dj., str. 6. 


\section{LITERATURA}

Antell, K. Why do college students use public libraries?: A Phenomenological study. // Reference \& User Services Quarterly 43, 3(2014), 227-236. [citirano: 2020-10-22]. Dostupno na: https://www.jstor.org/stable/20864204?seq=1\#metadata_info_tab_ contents.

Aparac-Gazivoda, T. Ali študenti potrebujejo knjižnice in zakaj = Trebaju li studenti knjižnice i zašto? // Knjižnica: glasilo Zveze bibliotekarskih društev Slovenije 40, 3/4(1996, 35-43.

Biancarosa, G.; C. E. Snow. Reading next: A Vision for action and research in middle and high school literacy: A Report to Carnegie Corporation of New York. 2nd ed. Washington DC: Alliance for Excellent Education, 2006. [citirano: 2010-10-22]. Dostupno na: https://www.carnegie.org/media/filer_public/b7/5f/b75fba81-16cb422d-ab59-373a6a07eb74/ccny_report_2004_reading.pdf.

Bouillet, D. Slobodno vrijeme zagrebačkih studenata: Prilika za hedonizam ili samoostvarenje. // Sociologija i prostor 46, 3/4(181/182)(2008), 341-367. [citirano: 202010-22]. Dostupno na:

file:///D:/Downloads/Sociologija_i_prostor_2008_3_4_06_Bouillet\%20(4).pdf.

Dewan, P. Reading in the age of continuous partial attention: Retail-inspired ideas for academic libraries. // Reference \& User Services Quarterly 58, 3(2019), 177-187. DOI: http://dx.doi.org/10.5860/rusq.58.3.7045.

Dimzov, S. Uloga sveučilišne knjižnice u digitalnom okruženju s obzirom na informacijsko ponašanje studenata humanističkih znanosti: Doktorski rad. Zadar: Sveučilište u Zadru, 2016. [citirano: 2021-03-03]. Dostupno i na: https://urn.nsk.hr/ urn:nbn:hr:162:880974.

Elliot, J. Academic libraries and extracurricular reading promotion. // Reference \& User Services Quarterly 46, 3 (2007), 34-43. [citirano: 2020-10-02]. Dostupno na: https://www.jstor.org/stable/20864694.

Franzen, J. How to be alone. New York: Farrar, Straus \& Giroux, 2002.

Fulgosi, S. Usmjereno čitanje. // Zbornik radova Čitanje za školu i život, IV. simpozij učitelja i nastavnika hrvatskoga jezika. / urednik M. Mićanović. Zagreb: Agencija za odgoj i obrazovanje, 2013. str. 116-125. [citirano: 2020-02-02]. Dostupno na: https://www.azoo.hr/app/uploads/uvezeno/images/izdanja/citanje/12.html.

Informacije: Gdje su i kako ih pronaći. [prezentacija] [citirano: 2020-12-05]. Dostupno na: https://www.pravo.unizg.hr/_download/repository/prezentacija_za_postdiplomante.ppt.

Juric, M. Čitanje u tiskanom i digitalnom okruženju: Doktorski rad. Zadar: Sveučilište u Zadru, 2017. [citirano: 2020-06-10]. Dostupno i na: https://urn.nsk.hr/urn:nbn:hr:162:167435. 
Kleedorfer, J.; M. Mayer; E. Tumpold. Čitati s voljom i razumom. Koprivnica: Hrvatsko čitateljsko društvo, 1998.

Krpan, K.; I. Klak Mršić; V. Cej. Primjena razvojne biblioterapije u radu s djecom i mladima u narodnoj knjižnici. // Vjesnik bibliotekara Hrvatske 61, 1(2018), 345-361. DOI: http://doi.org/10.30754/vbh.61.1.621.

Lasić-Lazić, J.; M. Laszlo; D. Boras. Informacijsko čitanje. Zagreb: Zavod za informacijske studije, 2008.

Lasić-Lazić, J.; S. Špiranec; M. Banek Zorica. Izgubljeni u novim obrazovnim okruženjima: Pronađeni u informacijskom opismenjivanju. // Medijska istraživanja 18, 1(2012), 125-142.

Lau, J. Smjernice za informacijsku pismenost u cjeloživotnom učenju: Završna verzija. Zagreb: Hrvatsko knjižničarsko društvo, 2011.

Leburić, A. Mladi i čitanje: Knjiga kao element popularne kulture. // Knjiga i slobodno vrijeme: Zbornik radova s Međunarodnog interdisciplinarnog stručnog skupa Knjiga i slobodno vrijeme, Split, Gradska knjižnica Marka Marulića, 24. rujna 2010. Split: Gradska knjižnica Marka Marulića, 2011. Str. 8-15.

Liu, Z. Reading behavior in the digital environment: Changes in reading behavior. // Journal of Documentation 61, 6(2005), 700-712. DOI: https://doi. org/10.1108/00220410510632040.

Mahaffy, M. In support of reading: Reading outreach programs at academic libraries. // Public Services Quarterly 5, 3(2009), 163-173. DOI: https://doi.org/10.1080/1522 8950902904267.

Mamić, S.; M. Nekić. Anksioznost kod studenata: Uloga perfekcionizma, netolerancije neizvjesnosti, ruminacije i usredotočene svjesnosti. // Društvena istraživanja 28, 2(2019), 295-314.

DOI: https://doi.org/10.5559/di.28.2.06.

Manguel, A. Povijest čitanja. Zagreb: Prometej, 2001.

Mellon, C. A. Library anxiety: A Grounded theory and its development. // College \& Research Libraries 47, 2(1986), 160-165. [citirano: 2021-02-03]. Dostupno na: https://crl.acrl.org/index.php/crl/article/view/14195/15641.

Menander. Sententiae 657. // Works. / ed. W. G. Arnott. Cambridge; London, 1969.

Mikuletič, N. Biblioterapija u školskoj knjižnici ili razgovor o knjizi. // Vjesnik bibliotekara Hrvatske 53, 2(2010), 133-140.

Novak, H. Anketno istraživanje zadovoljstvo korisnika Gradske knjižnice Zadar. // Vjesnik bibliotekara Hrvatske 53, 3/4(2010), 140-157.

Opća deklaracija o ljudskim pravima. [citirano: 2020-10-10]. Dostupno na: http://www.mvep.hr/custompages/static/hrv/files/081210_deklaracija_ljudska_prava.pdf. 
Paul, R.; L. Elder. How to read a paragraph: The Art of close reading. 2nd ed. Lanham etc.: Rowman \& Littlefield, 2013. [citirano: 2020-02-20] Dostupno na:

https://books.google.hr/books?id=BDWbDwAAQBAJ\&printsec=frontcover\&dq=how + to + read $+\mathrm{a}+$ paragraph $\& \mathrm{hl}=\mathrm{hr} \& \mathrm{sa}=\mathrm{X} \& \mathrm{ved}=0 \mathrm{ahUKEwiUra-P1rLlAhUMb}-$ cAKHUP5CsIQ6AEIJjAA\#v=onepage \&q=how $\% 20$ to $\% 20 \mathrm{read} \% 20 \mathrm{a} \% 20$ paragrap$\mathrm{h} \& \mathrm{f}=$ false

Peti-Stantić, A. Čitanjem do (spo)razumijevanja: Od čitalačke pismenosti do čitateljske sposobnosti. Zagreb: Naklada Ljevak, 2019.

Petr Balog, K. Prema kulturi vrednovanja u visokoškolskim knjižnicama. Osijek: Filozofski fakultet Sveučilišta J. J. Strossmayer u Osijeku, 2010.

PISA 2009: Čitalačke kompetencije za život. / uredila M. Braš Roth. Zagreb: Nacionalni centar za vanjsko vrednovanje obrazovanja - PISA centar, 2010.

Plevnik, D. Fortuna čitanja. Osijek: Hrvatsko čitateljsko društvo, 2006.

Pšihistal, R. O književnosti kroz dimenziju čitanja/hranjenja. // Zbornik radova Čitanje za školu i život, IV. simpozij učitelja i nastavnika hrvatskoga jezika. / urednik M. Mićanović. Zagreb: Agencija za odgoj i obrazovanje 2013. str. 42-55. [citirano: 2021-03-02]. Dostupno na:

https://www.azoo.hr/app/uploads/uvezeno/images/izdanja/citanje/06.html.

Rathe, B.; L. Blankenship. Recreational reading collections in academic libraries. // Collection Management 30, 2(2006), 73-85. DOI: https://doi.org/10.1300/ J105v30n02_06.

Rudež, J. Bibliografska metodologija. // Hrvatski 2, 1/2(2004), 56-66.

Sabolović-Krajina, D. Neki aspekti čitalačke kulture mladih. // Vjesnik bibliotekara Hrvatske 32, 1/4(1989), 71-94.

Standardi i smjernice razvoja i uvođenja najbolje prakse u visokoškolskim knjižnicama. [citirano 2021-03-04]. Dostupno na: https://www.hkdrustvo.hr.

Stričević, I. Čitanje u kontekstu školskih i narodnih knjižnica: Uloga knjižnica u poticanju funkcionalnog čitanja i čitanja iz užitka. // Čitanje - obaveza ili užitak: Zbornik. / priredila R. Javor. Zagreb: Knjižnice grada Zagreba, 2009. Str. 41-49.

Stričević, I.; S. Jelušić. Informacijske potrebe i čitateljski interesi građana Hrvatske. // Knjiga i slobodno vrijeme: Zbornik radova. / Međunarodni interdisciplinarni stručni skup Knjiga i slobodno vrijeme, Split, Gradska knjižnica Marka Marulića, 24. rujna 2010. Split: Gradska knjižnica Marka Marulića, 2011. Str. 16-31.

Tomašević, N. Istraživanje stajališta o čitanju i njihov utjecaj na nakladništvo: Ocjena zainteresiranosti za književne vrste. // Libellarium 1, 2(2008), 221-242. DOI: http:// dx.doi.org/10.15291/libellarium.v1i2.131.

To read or not to read: A Question of national consequence: Research report 47. Washington DC.: National Endowment for the Arts, Office of Research and Analysis, 
2007. [citirano: 2020-01-10]. Dostupno na: https://www.arts.gov/sites/default/files/ ToRead.pdf.

University of Oxford. Reading at 16 linked to better job prospects. // ScienceDaily. 9 May (2011). [citirano: 2020-10-22]. Dostupno na: www.sciencedaily.com/releases/2011/05/110504150539.htm.

Velagić, Z. Povijesnost koncepcije knjižničnog trećeg prostora. // Narodne knjižnice kao treći prostor: Zbornik radova 9. savjetovanja za narodne knjižnice u Republici Hrvatskoj. / uredile D. M. Gabriel i J. Leščić. Zagreb: Nacionalna i sveučilišna knjižnica, 2015. Str. 29-42. 